\title{
DÜBLIN
}

Technological University Dublin

ARROW@TU Dublin

1999-01-01

\section{Note on the Voltammetry of Ferrocene Carboxylate in Aqueous Solution}

\author{
John Cassidy \\ Technological University Dublin, john.cassidy@tudublin.ie \\ John O'Gorman \\ Technological University Dublin \\ M. Ronane \\ Technological University Dublin
}

See next page for additional authors

Follow this and additional works at: https://arrow.tudublin.ie/scschcpsart

Part of the Chemistry Commons

\section{Recommended Citation}

Cassidy, J.F., O'Gorman, J., Ronane, M., Howard, E.:Note on the Voltammetry of Ferrocene Carboxylate in Aqueous Solution. Electrochemistry Communications, Vol.1, 2, 1999, pp.69-71. doi:10.1016/

S1388-2481(99)00007-7

This Article is brought to you for free and open access by the School of Chemical and Pharmaceutical Sciences at ARROW@TU Dublin. It has been accepted for inclusion in Articles by an authorized administrator of ARROW@TU Dublin. For more information, please contact arrow.admin@tudublin.ie, aisling.coyne@tudublin.ie, gerard.connolly@tudublin.ie.

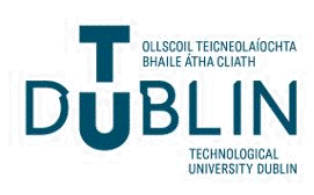




\section{Authors}

John Cassidy, John O'Gorman, M. Ronane, and Enda Howard

This article is available at ARROW@TU Dublin: https://arrow.tudublin.ie/scschcpsart/13 


\title{
Note on the voltammetry of ferrocene carboxylate in aqueous solution
}

\author{
J. Cassidy *, J. O'Gorman, M. Ronane, E. Howard \\ School of Chemistry. Dublin Instinute of Technology، Kevin Street, Dublin 8, Ireland
}

Received 29 December 1998; received in revised form 25 January 1999; accepted 2 February 1999

\begin{abstract}
Cyclic voltammetry of ferrocene dicarboxylate in aqueous solutions at high $\mathrm{pH}$, in the presence of oxygen, showed evidence of an $\mathrm{EC}^{\prime}$ mechanism where the oxidised form of ferrocene dicarboxylate reacts with $\mathrm{HO}_{2}^{-}$, which had been produced at a lower potential. However, an analogous experiment with ferrocene carboxylate yielded a cyclic voltammogram with a post peak following the anodic peak for ferrocene carboxylate. The reason for the post peak is not clear but may be due to a delay in the reaction between the oxidised form of ferrocene carboxylate and $\mathrm{HO}_{2}^{-}$. (c) 1999 Elsevier Science S.A. All rights reserved.
\end{abstract}

Koywords: Cyclic voltammetry; Oxygen reduction; Ferrocene carboxylate; Ferrocene dicarboxylate

\section{Introduction}

Ferrocene and its derivatives have formed the basis of many mediation systems especially in second-generation mediator systems with enzymes [1,2], a popular case in point being glucose oxidase [3]. The electrochemistry in nonaqueous solutions has been characterised to the extent that ferrocene has been used as a reference couple with respect to which potentials are quoted [4]. It has been used for this purpose for the electrochemistry of oxygen in DMF, DMSO and acetonitrile [5]. The purpose of this note is to describe preliminary work on the electrochemistry of ferrocene carboxylate $(\mathrm{FcA})$ in aqueous solution in the presence of oxygen.

\section{Results and discussion}

As a comparison, the electrochemistry of 1,1'-ferrocene dicarboxylate (FcDa) is shown in Fig. 1 both in the presence of air and in a solution which has been bubbled with oxygen. The electrochemical arrangement has been reported previously [6] and the main difference between this work and previous work is that the cyclic voltammetry is carried out at slower sweep rates. In the presence of oxygen the following reduction occurs [7]:

$2 \mathrm{O}_{2}+2 \mathrm{e}^{-} \rightarrow 2 \mathrm{O}_{2}^{-}$

$$
4779
$$

* Corresponding author. Tel.: + 351-1 402 3006; Fax: + 351-1 402 4999; E-mail: jcassidy@ditie

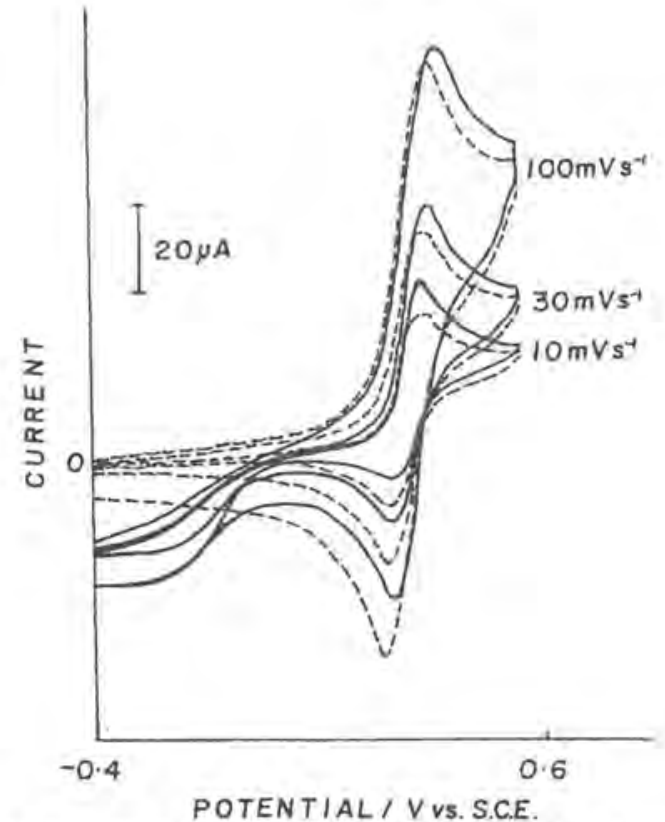

Fig. 1. Cyclic voltammograms of FCDa $\left(10^{-2} \mathrm{~mol} \mathrm{dm}^{-3}\right)$ in borate buffer (pH 10) at a glassy carbon electrode: $(--)$ in air; $(\stackrel{\square}{\longrightarrow}$ solution bubbled with oxygen for $10 \mathrm{~min}$. Sweep rates 100,30 and $10 \mathrm{mV} \mathrm{s}^{-1}$.

$2 \mathrm{O}_{2}^{-}+\mathrm{H}_{2} \mathrm{O} \rightarrow \mathrm{O}_{2}+\mathrm{HO}_{2}^{-}+\mathrm{OH}^{-}$

At the initial potential ( $-0.4 \mathrm{~V}$ versus SCE), the reduction of oxygen occurs and the superoxide reacts immediately with water to yield $\mathrm{HO}_{2}^{-}$and, thus, the oxygen reduction reaction can be represented as the sum of reactions (1) and (2). At the initial potential ( $-0.4 \mathrm{~V}$ versus SCE), oxygen is reduced 
at the working electrode. As the potential is swept the FcDa is oxidised. Ferricenium dicarboxylate then reacts with the reduced form of oxygen as follows:

$2 \mathrm{FcDa}^{+}+\mathrm{HO}_{2}^{-}+\mathrm{OH}^{-} \rightarrow \mathrm{O}_{2}+2 \mathrm{FcDa}^{-} \mathrm{H}_{2} \mathrm{O}$

thus regenerating $\mathrm{FcDa}$ in an $\mathrm{EC}^{\prime}$ mechanism [8]. As such the forward peak increases and the reverse peak decreases. The oxidation peak for FcDa is $0.368 \mathrm{~V}$ versus SCE. In the case of ferrocene carboxylate (FcA) shown in Fig. 2 the oxidation peak is $0.277 \mathrm{~V}$ versus SCE and it would be reasonable to imagine a similar behaviour between ferricenium carboxylate and $\mathrm{HO}_{2}^{-}$. However, the cyclic voltammetry of FcA in the presence of air is not as simple (Fig. 2), It can be seen at slower sweep rates that there is a post peak subsequent to the oxidation peak of FcA. This peak occurs at $0.317 \mathrm{~V}$ versus SCE; it shifts to more positive potentials with increasing sweep rate and its magnitude decreases. There are a few points to mention about this post peak:

(a) It occurs to the same extent at glassy carbon, Pt and Au. This implies the process is not a simple adsorption process that varies depending on the electrode material. It can only be seen clearly at slow sweep rates of $20 \mathrm{mV} \mathrm{s}^{-1}$ or less and there is no corresponding reduction peak. At faster sweep rates the reduction of ferricenium outruns the rate of the subsequent chemical reaction.

(b) The post peak disappears when the solution is degassed with nitrogen and its magnitude increases with increasing concentration of FcA up to $10 \mathrm{mM}$ and/or oxygen where the solution is saturated with oxygen.

(c) The post peak is still present when enough $\beta$-cyclodextrin is added $(20 \mathrm{mM})$ to the solution to ensure that FcA is complexed [6]. The formal potential of the complex is more positive than that of uncomplexed $\mathrm{FcA}$ and the current decrease indicative of complexation, but the post peak is still present. When complexed with $\beta$-cyclodextrin, only the dissociated FcA reacts at the electrode since the complexed FcA is shielded because of its inclusion in the cavity and will not have direct contact with the electrode for electron transfer to take place. The mediation therefore occurs when FcA has left the cavity, become oxidised and before it is recomplexed with $\beta$-cyclodextrin.

(d) The post peak does not appear when FcA is not present; there is no anodic current corresponding to the oxidation of $\mathrm{HO}_{2}^{-}$in the background electrolyte alone at the potential where the post peak occurs.

(e) In the presence of FCA, the post peak does not occur at lower $\mathrm{pH}$, for example in $0.1 \mathrm{M} \mathrm{KCl}, 0.1 \mathrm{M} \mathrm{LiClO}_{4}$, even when bubbled with oxygen. The $\mathrm{p} K_{\mathrm{a}}$ for FcA is 4.2 and thus it should completely dissociate under these conditions. At this $\mathrm{pH}$ the $\mathrm{O}_{2}$ is not reduced at the initial potential $(0.0 \mathrm{~V}$ versus $\mathrm{SCE}$ ).

(f) No post peak occurs when the cyclic voltammogram of FcA is run in acetonitrile when $\mathrm{H}_{2} \mathrm{O}$ is deliberately added to a concentration of $6.3 \mathrm{~mol} \mathrm{dm} \mathrm{dm}^{-3}$. The addition of water causes a shift in the formal potential of FcA from which it

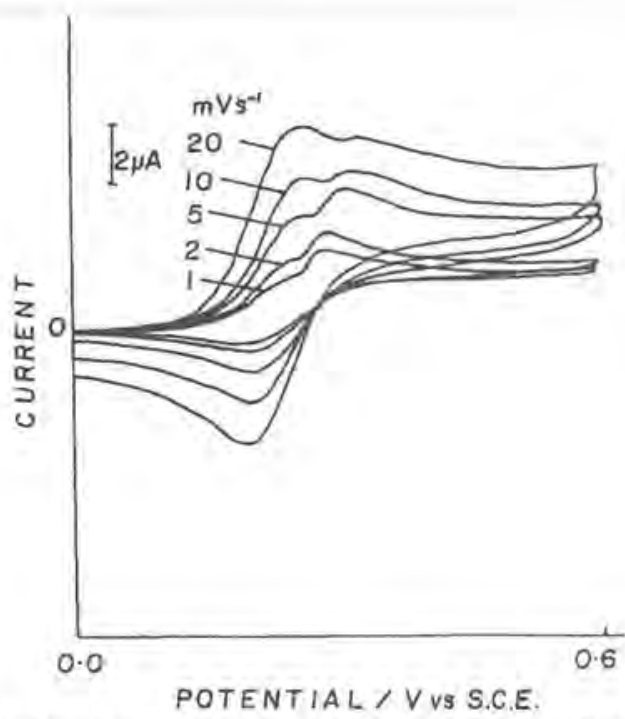

Fig. 2. Cyclic voltammograms of FcA $\left(10^{-1} \mathrm{~mol} \mathrm{dm}^{-3}\right)$ in $\mathrm{Nil}_{2} \mathrm{HPO}_{4}(0.2$ $\mathrm{M}, \mathrm{pH} \mathrm{9.2)} \mathrm{at} \mathrm{a} \mathrm{gold} \mathrm{working} \mathrm{electrode} \mathrm{in} \mathrm{the} \mathrm{presence} \mathrm{of} \mathrm{air.} \mathrm{Sweep} \mathrm{rates}$ are indicated in the plot.

can be deduced that there is one water molecule complexed to each ferrocene carboxylate in acetonitrile [9].

( $g$ ) The post-peak magnitude increases as the initial potential is made more negarive (from 0.0 to $-0.4 \mathrm{~V}$ versus $\mathrm{SCE}$ ) since there is a greater quantity of $\mathrm{HO}_{2}^{-}$present for reaction with the oxidised form of FcA. The magnitude of the post peak increases with the lime that the cell is beld at $0,0 \mathrm{~V}$ versus SCE prior to sweeping the potential. It is interesting to compare the differences in voltammetry between monoand disubstituted ferrocene. The presence of a post peak implies that there is a delay in a reaction which could be an induction period before the reaction takes place or characteristic of the $\mathrm{EC}^{\prime}$ reaction.

Fig. 3 shows an overlay of a cyclic voltammogram of FcA in a degassed solution and a solution that is saturated with oxygen. It can be clearly seen that the post peak appears on

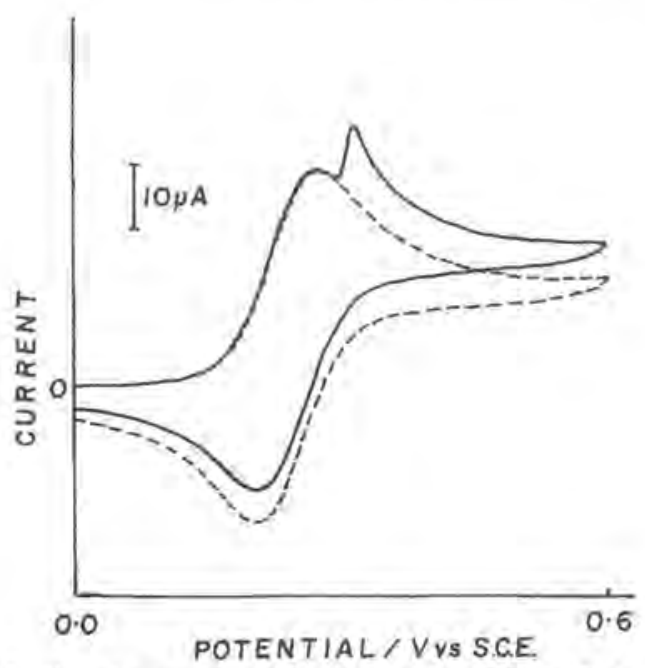

Fig. 3. Cyclic voltammograms of a saturated solution of FCA at a gold electrode in $0.1 \mathrm{~mol} \mathrm{dm}{ }^{-3} \mathrm{Na}_{2} \mathrm{HPO}_{4}(\mathrm{pH} 9.2)$ bubbled with nitrogen (-.. ) and bubbled with oxygen ( $\longrightarrow$. Sweep rate $10 \mathrm{mV} \mathrm{s}^{-1}$. 
the decay of the first peak without affecting the magnitude of the first peak. A clearer idea of the mechanism would be gained from the study of the effect of varying FcA concentration, $\mathrm{O}_{2}$ concentration and $\mathrm{pH}$, and perhaps examining other derivatives of ferrocene.

\section{Acknowledgements}

The authors would like to thank the Reviewers for their useful comments.

\section{References}

[1] B.R. Eggins, Biosensors, An Introduction, Wiley-Teubner, Chichester. 1996.
I2] M.M. Morris, G.L. Kok, in: A.J. Bard, H. Lund (Eds.), Encyclopedia of Electrochemistry of the Elements. Marcel Dekker. New York, 1979.

[3] A.E.G. Cass, G. Davis, G.D. Francis, H.A.O. Hill, WJ. Aston, I.J. Higgins, E.V. Plotkin, L.D. Scott, A.PF. Turner, Anal. Chem. 56 (1984) 657.

[4] G. Gritzner, J, Kuta, Pure Appl. Chem, 56 (1984) 461.

I5] D. Vasudevan, H. Wednt. J. Electroanal. Chem. 392 ( 1995) 69.

[6] S. McCormack, N.R. Russell, J. Cassidy, Electrochim. Acta 37 (1992) 1939.

[7] J.O'M. Bockris, S.U:M. Khan, Surface Electrochemistry, Plenum. New York, 1993, pp. 319-343.

[8] A.J. Bard, L.R. Faulkner, Electrochemical Methods, Fundamentals and Applications, Wiley, New York, 1980.

[9] R.E. Nottle, D. Pletcher, J. Electroanal. Chem. 293 (1990) 273. 